\title{
REPRESENTATIVIDADE IDENTITÁRIA DA FIGURA FEMININA NO DISCURSO DA MINISTRA DAMARES ALVES
}

\author{
IDENTITY REPRESENTATIVENESS OF THE FEMALE FIGURE \\ IN THE SPEECH OF MINISTER DAMARES ALVES
}

\author{
Dina Maria Martins Ferreira' \\ [ORCID: https://orcid.org/0000-0003-2585-497X] \\ lara de Sousa Nascimento ${ }^{2}$ \\ [ORCID: https://orcid.org/0000-0002-5761-4076] \\ DOI: https://doi.org/10.30612/raido.v14i36.11435
}

\begin{abstract}
RESUMO: Inserida em um cenário sociopolítico que tem sido propício para o fortalecimento de um discurso conservador, a sociedade brasileira, desde o ano de 2019, conta com a ministra Damares Alves na chefia do Ministério da Mulher, da Família e Direitos Humanos. Diante deste contexto e da importância de seu papel enquanto mulher e representante do povo, pretende-se, neste trabalho, analisar a construçăo da identidade feminina no discurso da ministra por meio de uma investigaçâo linguística, discursiva e social apoiada na Análise de Discurso Crítica de vertente dialética-relacional (FAIRCLOUGH, 2001 [1992], 2003), além de teorias acerca dos Perfis Identitários Femininos (MARTINS FERREIRA, 2009 [2002], 2010 2017), Identidades Performativas e Gênero (PINTO, 2002, 2007; BUTLER, 1993, 2017). A análise é realizada em material transcrito proveniente de um vídeo do Youtube publicado no canal "Câmara dos Deputados", em abril 2019, e revela que o perfil identitário da ministra apresenta uma postura alinhada a preceitos patriarcalistas que colocam a mulher em posiçâo de submissâo em relaçâo ao homem, discurso este atrelado ao discurso religioso e conservador.
\end{abstract}

Palavras-chave: discurso; feminilidade; feminilitude; performatividade

ABSTRACT: Inserted in a socio-political scenario that has been conducive to the strengthening of a conservative discourse, Brazilian society, since 2019, has Minister Damares Alves at the head of the Ministry of Women, Family and Human Rights. In light of this context, and of the importance of her role as a woman and representative of the people, this work aimes to analyze the construction of female identity in the minister's speech through a linguistic, discursive and social investigation supported by the Critical Discourse Analysis of relational- dialectical aspect (FAIRCLOUGH, 2001

Universidade Estadual do Ceará (UECE), Centro de Humanidades, Programa de Pós-Graduaçăo em Linguística Aplicada, Fortaleza, Ceará, Brasil; pós-doutora; professora visitante. Sorbonne V, Paris, França, Centre d'Etudes sur les Actuels et le Quotidian (CEAQ), pesquisadora-membro. Email: dinaferreira@terra.com.br

2 Universidade Estadual do Ceará (UECE), Centro de Humanidades, Programa de Pós-Graduaçăo em Linguística Aplicada; mestranda.Email: sousa.yara15@gmail.com 
[1992], 2003), beyond theories about Female Identity Profiles (MARTINS FERREIRA, 2009 [2002], 2010, 2017), Performative Identities and Gender (PINTO, 2002, 2007; BUTLER, 1993, 2017) the "Câmara dos Deputados" channel, on April 2019, and reveals that the minister's identity profile has a posture aligned with patriarchal precepts that place women in a position of submission in relation to man, linked to religious and conservative discourse.

Keywords: discourse; feminility; feminilitude; performativity

\section{INTRODUÇÃO}

Com a extensăo da divulgaçăo e do alcance do movimento feminista e suas pautas, mulheres têm conquistado um espaço maior em diversos setores da sociedade, no entanto, no espaço político a representatividade feminina ainda se encontra de maneira tímida. A prova disto é que, no Brasil, onde a política tem sido um dos alvos da luta por representatividade, conta com apenas $16,20 \%{ }^{3}$ de participaçăo feminina no congresso. Este número ainda é insignificante se considerarmos que, segundo a Pesquisa Nacional por Amostra de Domicílios Contínua (PNAD) de 20184, a populaçăo brasileira é composta por $48,3 \%$ de homens e $51,7 \%$ de mulheres. Ou melhor, mesmo havendo mais mulheres no âmbito populacional e a ministra Damares Alves aumentar este percentual, a ministra defende pautas conservadoras que contrariam as conquistas feministas.

Diante da tentativa por representatividade, muitas mulheres, sobretudo as executivas e as políticas, têm aderido a novas configuraçôes identitárias que se ancoram em atributos e valores naturalizados como pertencentes ao universo masculino (MARTINS FERREIRA, 2010). Assim, aquelas que detêm um certo nível de poder, tendem a possuir um perfil que abrange qualificaçôes (competência força, coragem...) que diferem daquelas que foram construídas pelo patriarcado (beleza, seduçăo, doçura...).

Contudo, o Brasil tem vivenciado um novo período político que aponta para um possível fortalecimento do discurso conservador, fenômeno que, assim como Lima (2018) o fez, consideramos como a materializaçăo de um alinhamento político que é ainda a favor da manutençâo de valores tradicionais em diversas instituiçôes, a exemplo da família, igrejas e escola. Tal pensamento, segundo a autora, tende a posicionar-se contra ideologias progressistas, que poderiam modificar perfis mais tradicionais.

Um dos fatores que vem contribuindo para (re-)estabelecimento da dominaçáo patriarcal, sobretudo na política, é o crescimento de igrejas evangélicas/neopentecostais e suas bancadas Congresso Nacional (CUNHA, 2016). Deste modo, tais elementos se tornam constitutivos "das ideologias presentes nos partidos de direita e de extrema-direita" (FERREIRA, 2016, p. 169), cooperando para o crescimento desta onda ideológica. A exemplo disto, há em nosso atual governo uma crescente força de políticos com esse perfil conservador e que representam uma boa parcela da populaçáo a favor

Disponível em: http://www.tse.jus.br/imprensa/noticias-tse/2019/Marco/numero-de-mulhereseleitas-em-2018-cresce-52-6-em-relacao-a-2014. Acesso em: 24 de março de 2020.

4 Disponível em: https://educa.ibge.gov.br/jovens/conheca-o-brasil/populacao/18320-quantidade-dehomens-e-mulheres.html. Acesso em: 13 de agosto de 2019. 
do fortalecimento de valores e práticas conservadoras e patriarcais. Dentro deste cenário, também se inserem mulheres que, interpeladas pelo machismo estrutural, reivindicam posicionamentos que pesam de maneira contrária a pautas feministas.

É neste âmbito que levantamos a preocupaçáo diante do fato de termos, atualmente, na liderança do Ministério da Mulher, da Família e Direitos Humanos, uma mulher que adota uma postura de cunho religioso e conservador, a ministra Damares Alves ${ }^{5}$, legislando a vida e a representatividade das mulheres brasileiras. Neste sentido, passamos a indagar se seus recursos textual-discursivos contribuem para uma identidade feminina marginalizadora(-da), ${ }^{6}$ ou se o discurso da ministra, dado seu poder político-representativo, poderia afetar $^{7}$ a veiculaçâo dos perfis identitários de mulheres brasileiras.

Assim, o objetivo central deste estudo é analisar a construçăo da representaçăo identitária feminina no discurso da ministra Damares Alves na ocasiâo da Comissâo dos Direitos das Mulheres transmitida pelo canal do Youtube Câmara dos Deputados, em dezesseis de abril de 2019. Além disso especificamos dois objetivos, que nâo sâo excludentes entre si, até podendo ser consequentes, ou seja, o primeiro gerando o segundo: (a): examinar os recursos textual-discursivos que săo mobilizados para construir a identidade feminina no discurso da ministra; e (b) caracterizar o(s) perfil(s) identitário(s) feminino(s) que emerge(m) a partir do discurso da ministra.

Quando nos preocupamos em carregar o título pela expressăo "representatividade identitária", nos apegamos ao discurso como prática social que nos propicia perceber volteios, modalizaçōes e sentidos do discurso na construçâo de valores (FAIRCLOUGH, 2001 [1992]) âmbitos que fornecem categorias analíticas para a desconstruçâo do discurso da ministra Damares, principalmente no que se refere à funçâo identitária da linguagem e ao sentido representacional construído no discurso, que alimenta os perfis da figura feminina. No que tange à abordagem teórica sobre linguagem performativa e identidade de gênero (AUSTIN, 1990; BUTLER, 1993), esta se faz como uma contrapartida analítica a um discurso essencialista e ontologizador (da ministra) que estratifica a representaçăo identitária da figura feminina, a um perfil patriarcal hegemônico âmbito argumentativo para as consideraçôes finais, que alude à nossa posiçâo como pesquisadoras.

Ressaltamos que năo pretendemos fazer inferências sobre a ministra em âmbito pessoal ou que gere alguma forma de desrespeito. Este artigo se debruça sobre uma análise textual-discursiva em pronunciamentos oficiais utilizando métodos e categorias que cientificizam o trabalho.

$6 \quad$ O sentido de uma identidade marginalizadora-(da) remete à ideia de uma mulher passiva, sem agência, colocada de lado diante das decisôes, no caso, politicas.

7 Aqui năo faremos uma análise sobre os efeitos ideológicos do discurso em questăo sobre a vida de mulheres, apenas reflexóes a partir corpus selecionado.

8 Por motivos de espaço e de informaçôes pertinentes a nossa análise, o corpus analítico é um recorte de trechos. A transcriçấo do vídeo foi feita com o auxílio do software InqScribe (Inquirium, s/d) junto a adaptaçóes do modelo de transcriçáo elaborado por Marcuschi (1997). No anexo encontra-se o fragmento discursivo, e dentro do texto, os fragmentos analíticos estăo em itálico para diferenciar das citaçóes referenciais. O vídeo na íntegra está disponível em: https://www.youtube.com/watch?v=cmZGROiWjgE. Acesso em: 22 de janeiro de 2020. 


\section{ANÁLISE DO DISCURSO CRÍTICA (ADC): PRÁTICA SOCIAL}

A Análise do Discurso Crítica (ADC) tem como principal nome o linguista britânico Norman Fairclough, localizando-se dentro das chamadas Ciências Sociais Críticas (CHOULIARAKI; FAIRCLOUGH, 1999 apud MAGALHÂES 2005), pois revela "como o discurso é moldado por relaçôes de poder e ideologias e os efeitos construtivos que o discurso exerce sobre as identidades sociais, as relaçóes sociais e os sistemas de conhecimento e crença" (FAIRCLOUGH 2001 [1992], p. 31).É importante salientar que a ADC "orienta-se linguisticamente pela Linguística Sistêmica Funcional (LSF) de Halliday" (RAMALHO; RESENDE, 2006, p. 56), fazendo uma espécie de releitura de alguns de seus conceitos. ${ }^{9}$ Desta forma, Fairclough (2001 [1992]) propóe novas reconfiguraçóes acerca das funçôes da linguagem quanto ao seu efeito constitutivo:

[...] o que denominarei as funçôes da linguagem 'identitária', 'relacional' e 'ideacional'. A funçăo identitária relaciona-se aos modos pelos quais as identidades sociais săo estabelecidas no discurso, a funçăo relacional a como as relaçóes sociais entre os participantes do discurso săo representadas e negociadas, a funçáo ideacional aos modos pelos quais os textos significam o mundo e seus processos, entidades e relaçōes (FAIRCLOUGH, , 2001 [1992], p. 92).

Pelas funçôes da linguagem, este autor mostra que o discurso é capaz nâo só de modificar nossa maneira de enxergar o mundo, mas também de construí-la, ou melhor: a funçâo ideacional revela como os textos carregam seu papel nos processos de significaçăo; a relacional representa o modo como nos relacionamos uns com os outros; e a identitária diz respeito aos modos como nossas identidades podem ser estabelecidas através do discurso.

Ademais, a ADC trouxe para os estudos linguísticos a possibilidade de estudar o discurso por um prisma que considera a sua relaçáo com as práticas sociais e, por conseguinte, com a sociedade. A esta perspectiva, Fairclough (2001 [1992]) chamou de Teoria Social do Discurso, uma proposta de modelo teórico-metodológico que discorre sobre o tripé: prática social, estrutura textual e prática discursiva. ${ }^{10} \mathrm{Em}$ sua abordagem dialética-relacional, este estudioso se propóe a fazer uma análise de discurso linguística unida ao "pensamento social e político" (FAIRCLOUGH, 2001 [1992], p. 89) relevantes à prática discursiva através de um modelo tridimensional de análise que leva em consideraçâo o nível textual, o discursivo e o social, além de respectivas categorias analíticas, escolhidas para cada nível: lexicalizaçăo, intertextualidade e ideologia, respectivamente.

Em nível textual, nos ocupamos com o estudo da categoria lexicalizaçâo, ${ }^{11}$ visto que esse tipo específico de análise "recai sobre as lexicalizaçōes alternativas e sua significância política e ideológica" (FAIRCLOUGH, 2001 [1992], p. 105), buscando investigar o

\footnotetext{
Para mais detalhes sobre a relaçăo entre a ADC e a LSF, ver Ramalho; Resende, 2006, p. 56.

Para melhor visualizar o modelo, ver Fairclough, 2001 [1992], pp. 100-101.

Fairclough ([1992] 2001) sugere o uso do termo lexicalizaçăo ao invés de vocabulário por compreender que tal termo teria significado limitado ao dicionário, enquanto lexicalizaçáo englobaria o contexto espaço-temporal das palavras. O uso de itálico nas categorias teóricas visa chamar a atençáo para os elementos que farăo parte de nossa análise, com o intuito de facilitar as eventuais retomadas de leitura. Também para efeitos de clareza de leitura algumas categorias analíticas estâo em itálico.
} 
sentido das palavras utilizadas que implicam escolhas políticas e ideológicas do sujeitos e as lutas de poder que as mobilizam.

Na dimensăo da prática discursiva, nos detemos na categoria intertextualidade, recurso discursivo no qual há a "ênfase sobre a heterogeneidade dos textos e um modo de análise que ressalta os elementos e as linhas diversos e frequentemente contraditórios que contribuem para compor um texto". (FAIRCLOUGH, 2001 [1992], p. 137), permitindo, assim, que se investigue como tais elementos săo articulados na construçāo das identidades femininas.

Quanto à dimensăo social, nossa análise foca a ideologia que, para o autor diz respeito às "significaçôes/construçôes da realidade [...] construídas em várias dimensôes das formas/sentidos das práticas discursivas e que contribuem para a produçâo, reproduçăo ou a transformaçăo das relaçôes de dominaçăo" e que "é investida na linguagem de várias maneiras, em vários níveis", (FAIRCLOUGH, 2001 [1992], pp. 117-118), que, por sua vez, reflete sobre a(s) ideologia(s) que subjazem ao discurso da ministra.

Na ampliaçăo teórica de Fairclough (2003), temos um aprimoramento no que diz respeito aos sentidos do discurso: sentido identificacional, sentido acional e sentido representacional.

No identificacional, que diz respeito à construçăo de identidades através dos textos, localiza-se a ideologia, via a categoria analítica avaliaçâo, mais precisamente, que diz respeito a "maneiras mais ou menos explícitas ou implícitas pelas quais os autores se comprometem com valores"12 (FAIRCLOUGH, 2003, p.171), deixando emergir sua subjetividade e opiniâo sobre aspectos do mundo:

Como maneira particular de se posicionar diante de aspectos do mundo, avaliaçóes sáo sempre parciais, subjetivas e, por isso, ligadas a processos de identificaçáo particulares. Caso tais processos envolvam posicionamentos ideológicos, podem atuar em favor de projetos de dominaçăo. (RAMALHO; RESENDE, 2011, p. 119)

Esta categoria analítica permite acessar traços textuais avaliativos que revelam posicionamentos ideológicos materializados no discurso em questăo. A avaliaçâo pode ser classificada em: (a) afirmaçóes avaliativas, que correspondem a elementos avaliativos explícitos que denotam aquilo que é desejável ou indesejável através da utilizaçăo de verbos, advérbios ou sinais de exclamaçấo; (b) afirmaçôes com modalidades deônticas, que avaliam através de termos que inferem sentido de necessidade ou obrigatoriedade; (c) avaliaçóes afetivas, que se referem a processos mentais afetivos, envolvendo sentimentos e reflexóes e que se manifestam de modo explícito; e (d) presunçóes valorativas, que aparecem de maneira mais implícita e conotam uma apreciaçáo valorativa. (RAMALHO; RESENDE, 2011)

Retomando os sentidos discursivos, o sentido acional estaria mais próximo do que Halliday $(1978,1994)$ chamou de funçăo interpessoal, na qual os sentidos presentes nos textos atuam como instrumento de açăo social, daí a concepçăo de texto como evento social. Já o sentido representacional permite perceber de forma mais particular a representaçáo da identidade feminina, porquanto é tida como o modo pelo qual o

12 Traduçáo livre. Texto original: "[...] more or less explicit or implicit ways in which authors commit themselves to values". 
mundo, suas relaçôes, concepçóes e pressuposiçóes săo construídas dentro dos textos (FAIRCLOUGH, 2003).

Além disto, é importante salientar que no pensamento de Fairclough (2003) a análise textual considera os três sentidos do discurso como coexistentes. Por exemplo, na frase "será uma menina", simultaneamente, atuam o sentido identificacional, como constituinte da identidade de alguém, o sentido acional, porquanto exerce uma açâo, e o sentido representacional, que identifica e representa uma concepçâo acerca do que se considera ser uma menina. Este enunciado, vinculado inicialmente aos pressupostos de Fairclough, nos conecta teoricamente aos pressupostos de Austin e às noçôes de gênero de Butler, ou seja, ao identificar (sentido identificacional) que é uma menina, estou fazendo uma açăo (dizer é fazer), que vai gerar efeitos (perlocucionais) e que, por sua vez, vâo criar representaçóes sociais da ordem de gênero (gênero e sexo).

\section{LINGUAGEM E GÊNERO}

Apesar de este item năo ser o âmago teórico de nossa análise, ele se faz importante na medida em que, ao adotarmos a questăo da representaçăo no que tange ao sentido representacional no discurso e à representaçăo identitária do feminino, o conceito de representaçâo náo se define como uma categoria fixa e estável. 0 discurso é entendido como prática social e, como tal, se constrói na e pela performatividade da linguagem. Ratificamos que performatividade sempre é tomada pelo caráter da iterabilidade (iter e itera, repetível e novo) (DERRIDA, 1967), ou seja, o repetível năo se traduz no mesmo, mas sim no novo que se realiza a cada repetiçăo.

\subsection{Performatividade da linguagem}

Austin (1990) traça um caminho diferente do que muitos filósofos de sua época faziam, ou seja, ao invés de buscar a veracidade dos enunciados, como era de praxe ser o foco da filosofia tradicional, afirma que estes năo poderiam ser nem verdadeiros nem falsos, "ainda que pudesse implicar a verdade ou falsidade de outros, o enunciado performativo năo existe senáo para fazer" (PINTO, 2002, p. 102). Mesmo havendo uma série de discussóes nos pressupostos de Austin (1990), nos detemos que em sua teoria dos Atos de Fala voltada para os enunciados performativos, detentores de uma espécie de força enunciativa, podendo ser ilocucionária ou perlocucionária. A caracterizaçâo desta força é dada em relaçăo às três dimensóes do ato de fala: ato locucionário, ato ilocucionário e ato perlocucionário:

Para Austin o ato de fala é composto de três partes, três atos simultâneos: um ato locucionário, que produz tanto os sons pertencentes a um vocabulário quanto a articulaçăo entre a sintaxe e a semântica, lugar em que se dá a significaçăo no sentido tradicional; um ato ilocucionário, que é o ato de realizaçấo de uma açăo através de um enunciado, por exemplo, o ato de promessa, que pode ser realizado por um enunciado que se inicie por eu prometo..., ou por outra realizaçăo; por último, um ato perlocucionário, que é o ato que produz efeito sobre o interlocutor. (OTTONI, 2002, p. 128) 
É importante salientar (como o fez Ottoni) que, para Austin, estes três tipos de atos acontecem simultaneamente, porquanto săo três dimensōes de um só ato e năo três tipos de atos diferentes. O ato locucionário diz respeito à dimensăo da açăo pura de dizer algo, com sua escolha lexical, implicando também sua sintaxe e semântica, o ato ilocucionário refere-se à força da açăo realizada ao dizer algo, e o ato perlocucionário é o efeito dessa força gerado sobre o interlocutor do discurso proferido/realizado.

Após o descarte da dicotomia entre atos constatativos e atos performativos, Austin busca propor uma teoria geral para os atos de fala, em que entra também o papel do sujeito. Inicialmente, este seria "um sujeito intencional consciente da totalidade do seu ato de fala" (PINTO, 2002, p. 102), o que foi alvo de críticas por Derrida (1990), pois tinha a possibilidade de fracasso/sucesso ancorada na intençâo do falante, tornando o contexto da enunciaçáo saturável e redutível. Como sugere Pinto (2002), uma teoria geral para os atos de fala deveria ser uma teoria radical, no sentindo de levar em conta o falante como parte da performatividade:

\begin{abstract}
Mas que teoria seria essa? Sem dúvida seria uma teoria radical dos atos de fala, uma teoria que levasse em conta o sujeito de fala como parte integrante da performatividade, e nunca somente fórmulas linguísticas ou condiçōes de fala. Uma visâo performativa da linguagem deve integrar a complexidade da condiçăo de sujeito de linguagem, e levar às últimas consequências a identidade entre dizer e fazer, insistindo na presença do ato na linguagem, ato que transforma - opera. (PINTO, 2002, p. 103)
\end{abstract}

Assim, ao considerar a linguagem como performativa, a teoria radical dos atos de fala dá conta de alcançar a complexidade do sujeito, nâo como consciente de todas suas escolhas linguísticas, agindo intencionalmente, mas como ser que é parte de um processo performativo onde a previsăo para as realizaçóes linguísticas é insaturável.

\title{
2.2 Gênero
}

Butler (1993) nos alerta para a necessidade de compreender "a performatividade nâo como o ato pelo qual um sujeito gera o que ele/ela nomeia, mas sim [pelo] poder reiterativo do discurso [que] produz os fenômenos que ele regula e constrange" (BUTLER, 1993, p. 3). A autora enfatiza a performatividade năo como um simples ato de gerar o que é nomeado, mas como um poder de reinteraçâo no discurso, que regula e constrange as práticas sociais, consideração que é de grande valia para nós, visto que acreditamos que as identidades sâo construçôes performativas realizadas pelos sujeitos ao longo de suas vidas, como um processo contínuo de formaçâo e afirmaçâo deles mesmos.

Ainda segundo Butler, o gênero é uma estilizaçáo do corpo, um significado assumido por um corpo já diferenciado sexualmente" (BUTLER, 2017, p. 31), ou melhor, um conjunto de açôes linguístico-corpóreas que se repetem ao longo do tempo a fim de produzir um significado. Enfim, gênero é socialmente constituído e performativizado pelo sujeito:

O que Butler está dizendo é que tais identidades sociais năo existem simplesmente (elas só têm "a aparência da substância"); ao contrário, elas săo criadas quando os atores sociais as realizam repetidamente. A razăo pela qual nos percebemos, e somos percebidos pelos outros, como tipos particulares de pessoas, é que repetimos 
as açōes que definem esses tipos de pessoas até que, no tempo, elas parecem ser uma parte fixa e integral de nossa natureza. (CAMERON, 1995, p. 16) $)^{13}$

Portanto, pensar em uma resposta para questóes que buscam entender o que determina gênero, se este surge antes do discurso ou năo, náo pode limitar-se ao sexo designado pelo nascimento, pois, por este enfoque, excluímos uma gama de possibilidades de gêneros que nâo estâo em conformidade com seu sexo biológico e caímos na concepçâo simplista do determinismo homem/mulher.

O discurso é anterior ao corpo e, mesmo havendo marcaçōes biológicas de sexo, é o discurso que constrói o gênero. No simples enunciado "É uma menina!", năo se está constatando características físicas, mas tentando performar, como se assim o pudesse, um discurso preexistente, já que "a nomeação do sexo é um ato de dominaçăo que cria e legisla a realidade social pela exigência de uma construçăo discursiva/perceptiva dos corpos, segundo os princípios da diferença sexual." (BUTLER, 2017, p. 200), criando uma falsa relaçăo lógica entre sexo biológico e gênero, quando na verdade é a linguagem que tem o poder de gerar e modificar o que é socialmente real.

\subsection{Feminino}

Junto às prerrogativas analíticas fornecidas pela ADC e a de gênero, aliamos as categorias feminilidade e feminilitude (MOI, 1995; MARTINS FERREIRA, 2009 [2002]) como complemento teórico-analítico, porquanto "a sociedade muitas vezes condiciona representaçôes identitárias que se impóe ao sujeito", năo somente como um ato puramente individual (MARTINS FERREIRA, 2010, p. 2). ${ }^{14}$

Ainda segundo esta autora, a categoria poder, - que aqui também muito nos interessa - quando investida pela figura feminina, pode assumir duas funçôes: o poder de seduçăo e o poder político. Seguindo tal perspectiva, ela nos aponta para duas possíveis faces da identidade feminina: feminilidade e feminilitude, respectivamente:

A feminilidade responderia pelo perfil de uma mulher tradicional que encarnaria
os protótipos das valoraçóes instauradas no/pelo sistema patriarcal - submissáo,
beleza, emoçăo. A feminilitude abarcaria os valores de uma mulher moderna,
gerenciadora de seu tempo e espaço, uma mulher que, muitas vezes, no exercício do
poder abre máo da feminilidade, já que poder pressuporia, no parâmetro patriarcal,
trânsito no masculino. (MARTINS FERREIRA, 2010, p. 5)

Portanto, feminilidade corresponderia a um perfil mais tradicional de identidade feminina, atributos e características comumente associados ao ser mulher pelo viés patriarcal, enquanto isso, feminilitude seria o perfil identitário no qual o sujeito feminino apropria-se de características valoradas como masculinas na rede patriarcal para

13 Traduçâo livre. Texto original "what Butler is saying is that such social identities do not simply exist (they only have 'the appearance of substance'); rather they are brought into being when social actors repeatedly perform them. The reason we perceive ourselves, and are perceived by others, as particular kinds of people is that we repeat the actions that define those kinds of people until in time they come to seem like a fixed and integral part of our nature."

14 Estamos nos detendo nestas duas possibilidades, devido a nossa escolha analítica, nâo postulando que nâo haveria outras possibilidades categorias. 
desempenhar funçóes de poder, independência e autoridade perante a sociedade.

As estratégias discursivas da mulher-feminilitude podem ser associadas às identidades de mulheres executivas, como nos mostrou a pesquisa de Martins Ferreira (2009 [2002]), ou a de uma mulher ocupante de cargo político, por exemplo. Neste perfil, a mulher, por estar em uma sociedade onde os atributos masculinos săo constantemente associados ao poder e à autoridade, se vê obrigada a trazer para si características naturalizadas como masculinas para obter eficácia e credibilidade em seu exercício de poder. Tal fato se dá, pois, naturalizou-se o mito de que mulheres nasceram para os cuidados domésticos e familiares, sem faculdades mentais suficientes para governar, por exemplo. Dado isto, a mulher no poder, comumente, só tem validada sua capacidade diante de seu revestimento como mulher-feminilitude, geralmente, abrindo măo de ser mulher-feminilidade nas instâncias de poder.

Sobre o discurso, no que tange à funçâo identitária, esta autora afirma que o feminino tem o papel de "representar/construir" (MARTINS FERREIRA, 2010, p. 13), ora edificando uma mulher agente, que vive em trânsito no meio masculino e que valida sua capacidade de ir além do tradicional, ora corroborando ainda a mulher tradicional que mantém estereótipos já naturalizados e que colocam a mulher em posiçáo de submissăo e fragilidade.

No entanto, năo é possível polarizar essas duas configuraçōes de identidades femininas. Se observarmos o exemplo da mulher-feminilitude, dona de uma empresa, por exemplo, ela năo consegue tăo facilmente (se é que consegue) se desvencilhar dos atributos impostos pela feminilidade. Há a pressão pela maternidade que, muitas vezes, é adiada em funçâo de sua profissâo, pois, quando se é mâe, năo se pode negar que há ainda o acúmulo de funçōes que a sobrecarregam, fora exigência pela beleza (ainda que contida) e assim por diante, isto é, um jogo de troca de faces que variam conforme o contexto a que as mulheres sáo expostas. É nesta mescla de características e atributos que se perfila a sujeitos femininos.

Enfim, neste percurso teórico-metodológico-analítico, a ADC (MAGALHÂES; MARTINS; RESENDE, 2017) oferece a possibilidade de uma análise linguística em sua materialidade textual - daí sua herança estruturalista, com a possibilidade de se sistematizar o estudo linguístico -, considerando textos como eventos, situados em um contexto sócio-histórico específico - herança do materialismo histórico. Além disto, preocupa-se em investigar o papel do discurso nas relaçóes de poder e construçôes de sentidos.

\section{FEMININO NO DISCURSO DA MINISTRA}

A luta entre o patriarcalismo hegemônico, com seus comportamentos, valores ou crenças, já começa a se manifestar desde o início do discurso em relaçâo à identidade do gênero feminino: ${ }^{15}$

Acredito sim, que o menino que tá na escola vai ter que aprender a respeitar menina, o menino lá na escola vai ter que aprender, inclusive, a proteger menina. ${ }^{16}$

\footnotetext{
15 Vale o esclarecimento de que a organizaçăo da ordem dos itens teóricos nem sempre corresponde à ordem analítica adotada, já que nos posicionamos que săo os dados que direcionam a teoria e náo vice-versa.

16 Com o objetivo de diferenciar a retomada do corpus em relaçăo às citaçôes, já que ambos estăo em recuo,
} 
Em nível textual, no que tange à lexicalizaçăo, o uso do vocábulo proteger revela uma concepçăo de que meninos estăo em posiçăo de maior força e poder em relaçáo às meninas, isto é, que estas encontram-se em papel de fragilidade, apontando para um sentido identificacional do identitário feminino correspondente ao da noçăo patriarcal de feminilidade. Neste sentido, um tipo de avaliaçăo ideológica se classifica como uma modalizaçăo deôntica, ao passo que a repetiçăo da expressăo vai ter que aprender denota explicitamente o sentido de obrigatoriedade, necessidade (RAMALHO; RESENDE, 2011).

No momento do discurso onde a ministra discutia sobre o papel da menina na escola em relaçáo ao menino:

eu náo quero que ele [o menino] apenas abra a porta do carro, deputada, eu quero que ele abra a porta da fábrica, do seu escritório, a porta da sua indústria, eu quero que ele abra a porta dos partidos, quero que ele abra a porta desse parlamento para que mais mulheres estejam aqui também,

no nível social, há indícios de acepçōes ideológicas patriarcalistas em que as mulheres ainda năo sâo capazes de atuar ativamente na conquista por seus espaços de representatividade, cuja contrapartida masculina deve preencher, ou seja, os homens o devem fazer pelas mulheres. Inclusive o verbo querer revela o próprio posicionamento ideológico da enunciadora. Tal postura remete ao costume tradicional de que homens devem abrir portas para mulheres, que, ao se tornar parte do senso comum, ganham maior força, modo eficaz de as ideologias dominantes serem perpetuadas (FAIRCLOUGH, 2001 [1992]), já que săo reproduzidas de maneira natural e contínua. Aqui também é possível identificarmos que os atos de fala proferidos podem gerar efeitos perlocucionários aparentemente positivos nos interlocutores, devido ao entusiasmo da ministra ao enunciar a representatividade feminina em diversas esferas da sociedade. Contudo, esta representatividade, oferecida e presenteada pelo poder político, é agenciada por homens, conferindo às mulheres uma postura passiva, própria da identidade feminina da feminilidade.

No trecho,

se mulher deve ser submissa $(+)^{17}$ éh, essa é uma fala (+) que eu fiz dentro da minha igreja (+) dentro da doutrina cristâ, sim, lá, nós entendemos que dentro do casamento homem e mulher, o homem é o líder do casamento (+) então essa é uma percepçâo lá, dentro da minha igreja, da minha fé, eu quero dizer que todas as mulheres vâo ter que ser submissas, baixar a cabeça para o patrâo, para o agressor, para os homens que estâo aí? Nâo, mas dentro da minha concepçâo cristâ, a mulher sim, no casamento, ela é submissa ao homem e isso é uma questāo de fé,

a ministra faz referência a outras vozes, deixando à mostra a intertextualidade no que tange ao nível discursivo. Ou melhor, a ministra, ao trazer à baila o discurso religioso com referência direta ao discurso cristăo sobre a submissâo da mulher, busca estabelecer uma separaçăo entre sua voz como pastora evangélica e a de ministra. Săo vozes que se contradizem já que se trata da mesma figura feminina enunciando: enquanto evangélica é uma mulher lá, dentro da minha igreja, submissa no casamento e subentende que fora da igreja é possível a independência feminina. Fairclough (2001 ([1992])

mesmo com diferentes medidas, utilizamos para os fragmentos do corpus itálico. O recuo dos fragmentos é de $2,5 \mathrm{~cm}$ e o das citaçōes de $4 \mathrm{~cm}$, conforme as normas.

17 O sinal (+) na transcriçăo significa pausa curta e (++), pausa longa. 
assume a possibilidade de haver contradiçôes na intertextualidade, já que considera que tal dimensăo de análise é "basicamente a propriedade que têm os textos de ser cheios de fragmentos de outros textos" (FAIRCLOUGH, 2001 [1992], p. 114), podendo haver assimilaçăo entre tais fragmentos ou, como neste caso, a contradiçấo.

Neste mesmo trecho, em nível textual, o uso do léxico líder reforça a concepçăo de que o homem está em posiçâo de superioridade e comando em relaçâo à mulher. Quanto ao léxico submissa, verifica-se um embate por significaçăo: de um lado, no contexto religioso é possível inferir positividade a valores como humildade e servilismo, e, de outro, a negatividade, com sentido pejorativo, servilismo ao agressor, ao patrâo, no qual o indivíduo submete-se (e é submetido) às situaçōes de humilhaçâo e/ou exploraçấo. A despeito deste embate, Fairclough (2001 ([1992]) afirma que a disputa por significaçóes e suas respectivas estruturas edificantes revelam formas de hegemonia ideológica que se manifestam neste nível micro social da língua.

O uso das expressôes deve ser submissa, vâo ter que ser submissa e ela é submissa denota uma avaliaçăo deôntica através da escolha por verbos no modo imperativo. A escolha destas expressóes infere um sentido de obrigatoriedade, revelando, novamente, que a enunciadora compartilha da ideologia patriarcal mulher-feminilidade , na qual acredita que o homem é o ser ativo em relaçăo à mulher, privando-a de suas próprias escolhas .

Nos atos de fala dentro da minha concepçâo cristâ, a mulher sim, no casamento, ela é submissa ao homem, a ministra assume explicitamente sua opiniăo quanto à submissâo feminina. Se, de um lado, tal ato de fala ilocucionário gera efeitos perlocucionários de reforço do conservadorismo patriarcal, porquanto sua voz é institucional e de representatividade nacional, de outro, para mulheres que sâo vítimas de algum tipo de violência de gênero por parte da figura masculina, o efeito perlocucionário é de reforço negativo às suas próprias vidas, já que isenta de culpabilidade qualquer tipo de dominaçâo, mesmo aquelas de caráter de violência física e moral.

Em,

sou contra o aborto, todo mundo sabe, mas isso nâo vai nortear a política do nosso ministério, eu tenho tanta coisa pra fazer, eu tenho tanta coisa pra fazer naquele ministério que o tema aborto, eu năo vou fazer essa discussăo, a discussăo é do parlamento e agora no judiciário, o que já está aí, a política pública com relaçāo ao aborto, ela já está aí pelo ministério da saúde, deixa o ministro manter ela lá, deixa o ministro cuidar disso, eu vou cuidar de mulheres, lutar pra a gente salve mulheres, mulheres no ventre materno, mulheres sofridas, mulheres machucadas, esse é meu papel,

o vocabulário contra, no nível textual, possui sentido de contrariedade, rejeiçăo, negaçâo, já que se trata de uma pauta combatida, majoritariamente, por grupos cristâos. Já o léxico cuidar (de mulheres) ${ }^{18}$ é um verbo que infere um sentido de fragilidade no sujeito que sofre a açăo, que se hiperboliza na expressăo no ventre materno, pouco usada coloquialmente e facilmente associada ao contexto religioso por sua ligaçăo com

18 Importante clarificar que quando a ministra pronuncia que vai cuidar de mulheres, năo está assumindo papel masculino, de protetor das mulheres, mas assumindo a sua funçāo no Ministério da Mulher. É uma contradiçấo que talvez a falante nem tenha percebido, pois está desvinculando o seu ser-mulher do seu ser-ministra. 
passagens bíblicas, em que o papel da mulher era a de procriadora sem dúvida, uma mulher-feminilidade. Esta expressăo, ventre materno, também leva a uma interpretaçâo ambígua, ou seja, entre salvar mulheres (e.g. abortando legalmente em vez de em clínicas clandestinas) e salvar mulheres-fetos, que na realidade fetos nâo săo mulheres.

Em nível discursivo, identificamos intertextualidade, ou seja, há referência a um discurso anterior sobre a questăo de as políticas públicas sobre o aborto nâo serem mais uma pauta do Ministério da Mulher, e sim do Ministério da Saúde, que está entâo em liderança masculina. Em nível social, pudemos notar que em isso nâo vai nortear a política do nosso ministério há uma afirmaçâo avaliativa explícita através do uso do advérbio năo, assim como em nâo vou fazer essa discussăo. E, em eu tenho tanta coisa pra fazer, eu tenho tanta coisa pra fazer naquele ministério, há uma afirmaçăo de modalizaçăo deôntica, inferindo sentido de obrigatoriedade, revelando que a ministra carrega em seu posicionamento ideológico uma afirmaçăo categórica e explícita de que a pauta do aborto seria excedente ao seu ministério que já tem tantas outras atribuiçôes.

No trecho,

nós temos parlamentares jovens, lindas, espetaculares, inteligentes, mulheres de todas as cores, mulheres de todas as raças,

os vocábulos do nível textual jovens, lindas, espetaculares e inteligentes atribuem à figura feminina, pelo menos dentro do parlamento, uma conformidade com os padróes estereotipados acerca da mulher jovialidade e beleza, qualidades que denotam a exigência valorativa da posiçâo feminina no social. Apesar dos léxicos/expressóes inteligentes, de todas as cores e de todas as raças poderem referendar a mulher-feminilitude, ao fazer parte de um conjunto semântico próprio da mulher-feminilidade, perde sua força agentiva no nível discursivo diante dos traços patriarcalistas da ideologia da enunciadora. Estes atos de fala e seus efeitos perlocucionais ratificam os estereótipos que acompanham o feminino no universo patriarcal.

Em,

nós temos uma ministra, que é uma mulher empoderada, quem poderia imaginar no passado que uma simples assessora do corretor estaria hoje falando aqui, conduzindo as políticas públicas para mulheres, dá certo, é possível qualquer uma de nós podemos chegar lá, isso é empoderamento da mulher,

o léxico empoderada, comumente usado em discussóes de pautas feministas para referir-se a conquistas na liderança política (e também na vida ordinária) da mulher, e mesmo diante da tentativa de dar agência à figura feminina, ainda soa contraditório dentro do campo discursivo da ministra, já que afirma anteriormente ser a favor da submissâo feminina em relaçâo ao homem. Ademais, o resgate do termo empoderamento, no que concerne à categoria intertextualidade do nível discursivo, revela a possibilidade da feminilidade alcançar a feminilitude, se auto-exemplificando: no passado [...] a voz de uma simples assessora; e hoje [...] a voz da líder que está conduzindo as políticas públicas para mulheres.

No trecho,

eu sou mulher (+) sem marido/ ele foi embora, me abandonou, tadinha de mim, foi embora/ e sou mâe de uma menina indígena, 
a escolha pelos léxicos abandonou e tadinha inferem sentido de fragilidade e pequenez diante da açâo masculina. Apesar da aparente intençâo de demonstrar a agência feminina, ao dizer eu sou mulher sem marido a mulher que pode se virar sem homem , está privilegiando, senáo enaltecendo, o status das mulheres casadas. Aqui, vemos que a ministra tenta dar a si um sentido identificacional feminino fora de um discurso conservador, que na verdade ratifica a passividade feminina, indicando uma avaliaçấo contraditória do papel do feminino na sociedade.

Já, no trecho,

quando a senhora fala sobre a educaçáo lá na escola, esse tema (violência contra a mulher) abordado na escola, de que forma a gente fazer isso, éh, valorizando a masculinidade, a feminilidade,

os léxicos masculinidade e feminilidade reforçam a padronizaçăo da dicotomia homem/mulher, em que se faz vigente um discurso conservador, da ordem religiosa, que silencia a feminilitude.

Em

A senhora perguntou sobre as mulheres trans, lésbicas, bissexuais, é um desafio, deputada, elas estâo aí, elas existem, elas sofrem,

o uso do léxico existem pode ser traduzido como ato de fala constatativo e năo performativo, ou seja, um verbo de ordem de uma existência metafísica, que năo é açăo, que apresenta outros sujeitos femininos pertencentes à comunidade LGBTQ+. Trata-se de uma intertextualidade no nível discursivo em que várias vozes emergem, e que, no entanto, no nível social estăo silenciadas pela mulher ministra evangélica, haja vista o ato de fala é um desafio, cujo sentido identificacional desses sujeitos está mais para uma avaliaçăo afetivo-política do que agentiva. O efeito perlocucional destes atos de fala pode gerar uma indiferença à desigualdade de gênero, pressupondo uma constatatividade de identidade feminina, quando identidade(s) só podem ser atribuídas pela sua natureza performativa, seja pela inclusấo ou exclusăo de sujeitos.

A representaçâo feminina, na figura da ministra, ainda se consolida na dicotomia homem/mulher, haja vista sua obrigaçăo, como representante governamental das mulher:

todo casal que vai casar no civil tem um edital de proclama e por que náo falar com esse casal que tá lá, a gente vai acompanhar esse casal, você vai ter seu casamento garantido se você passar por uma palestra, um cursinho, por que nâo? por que nâo investir/ o estado está impondo/mas o estado vai ter que assumir seu papel e entender que precisa fazer alguma coisa (+) as vezes de forma impositiva.

Os léxicos garantido e impondo săo verbos que denotam sentido de uma açăo autoritária e interventiva por parte do Estado, porquanto há que precisa[r] fazer alguma coisa para garantir a legitimidade do casamento civil. Nos atos de fala todo casal que vai casar no civil tem um edital de proclama, a imposiçâo se reforça pela modalizaçăo deôntica no nível discursivo, que, por sua vez, se institucionaliza-se no nível social.

\section{CONSIDERAÇÕES FINAIS}

A performatividade do discurso de Damares Alves adquire um aparente contorno de atos de fala constatativos, propiciando a sedimentaçăo dos estereótipos de 
feminilidade e coloca a possibilidade de feminilitude na funçâo social do masculino. A ministra se esquece de que seu discurso é performativo e que constrói sua própria identidade, suas ideias e suas ideologias, cujas consequências a faz receber o papel de conservadora. E como representante governamental traz consigo toda uma representatividade feminina patriarcal, em que o papel da mulher da sociedade é o da passividade em contrapartida a agência masculina. Nâo é à toa, inclusive, uma abordagem midiática em que fala que os meninos devem se vestir de azul, enquanto as meninas de rosa, como se o corpo biológico fosse obrigatoriamente selado ao gênero do sujeito, e, como tal, a uma determinada estilizaçăo do corpo. Apesar de năo termos trabalhado com a noçấo de gênero como orientaçăo sexual, chamamos à baila este conceito, porquanto o discurso da ministra aloca a figura feminina sempre em face ao homem, ao casamento hétero, à heteronormatividade. A figura da mulher é transmitida como uma figura submissa e só é admitida no par da heterossexualidade do casamento.

Em relaçăo aos sentidos discursivos, o sentido identificacional nos permitiu aventar sobre a ideologia conservadora, senâo patriarcal de uma representante governamental, cujas avaliaçôes discursivas confirmam sua posiçâo ideológica. O sentido acional é construído sob a égide da igualdade de gênero no feminino, sem possibilidades de aceitar as desigualdadades. E o sentido representacional é o que fortalece, senáo, é o envolve todo o discurso no que tange ao modo como as concepçôes e pressuposiçóes sobre a figura feminina sâo construídas no discurso.

As pontuaçóes sobre as categorias analíticas, lexicalizaçăo, intertextualidade e ideologia, como o próprio termo pontuaçôes indica, foram os pontos nodais de nossa análise que nos forneceram esteio para indicar que a representaçâo identitária do feminino, no discurso da ministra Damares Alves, é a representaçâo que confirma e legisla o patriarcalismo social que ainda é semeado pelo Estado.

Ademais, a existência de (pelo menos) dois perfis identitários - feminilidade e feminilitude - nos fez reafirmar que o sujeito feminino transita predominantemente na feminilidade em detrimento da feminilitude. Neste sentido, ratifica-se que os trechos analisados contribuem para a construçăo de uma identidade feminina, a partir da figura de Damares, em que acreditamos "relacionar-se aos modos pelos quais as identidades sociais sáo estabelecidas no discurso" (FAIRCLOUGH, 2001 [1992], p. 92). E tal construçăo discursiva aponta especificamente para um perfil identitário feminino correspondente, em grande maioria, à noçăo patriarcal de feminilidade. Isto é, o discurso de Damares, enquanto ministra e também mulher e claramente atrelado ao discurso religioso conservador, legitima uma postura submissa da mulher, reforçando a dominaçâo masculina, apesar de algumas incoerentes tentativas de afirmar o contrário.

Em conclusăo, notamos a quebra de uma possível agentividade identitária de mulheres que alcançam liderança política, até porque uma das características da (re-)produçâo do sexismo no discurso é fato usar o primeiro nome para se referir a mulheres, mas nunca a homens. A maioria das mulheres em cargos políticos tendem a assumir valores contraditórios, inclusive utilizando-se de posturas mais "masculinizadas", que fortalecem valores patriarcais e que colocam a mulher em papel menos privilegiado em relaçăo ao homem solidifica-se, entăo, um perfil identitário feminino correspondente à feminilidade, representaçăo que condiz com o arquétipo patriarcal. 


\section{REFERÊNCIAS}

AUSTIN, J. L. Quando dizer é fazer: Palavras e açâo. Traduçăo de Danilo Marcondes de Souza Filho. Porto Alegre: Artes Médicas,1990.

BUTLER, J. Bodies that Matter: On the Discursive Limits of Sex. New York: Routledge, 1993.

BUTLER, J. Problemas de gênero: Feminismo e subversâo da identidade. Traduçâo de Renato Aguiar. 15ª ed. Rio de Janeiro: Ed. Civilizaçăo Brasileira, 2017.

CAMERON,D.VerbalHygiene.London:Routledge,1999.Disponívelem: https://www.academia.edu/32920654/Deborah_Cameron_Verbal_Hygiene_Politics_of_Language_1995 Acesso em: 11 de julho de 2019.

CUNHA, M. do N. Entre Ausências e Emergências: a Epistemologia do Sul, de Boaventura de Souza Santos e a pesquisa em Mídia, Religiāo e Política. XXXIX CONGRESSO BRASILEIRO DE CIÊNCIAS DA COMUNICAÇĀO Portal Intercom, Sociedade Brasileira de Estudos Interdisciplinares da Comunicaçăo, Săo Paulo, 2016. Săo Paulo. Disponível em: $\quad$ http://portalintercom.org.br/anais/nacional2016/resumos/R11-1901-1.pdf Acesso em: 5 out. 2019.

DERRIDA, J. De la Grammatologie. Paris: Éditions Minuit, 1967.

DERRIDA, J. Signature événement contexte. In: . Limited Inc. Paris: Éditions Galilée. 1990, p. 15-51.

FAIRCLOUGH, N. L. Discurso e mudança social. Traduçăo de Izabel Magalhăes. Brasília: Editora Universidade de Brasília, 2001 [1992].

FAIRCLOUGH, N. L. Analysing Discourse: textual analysis for social research. London: Routledge, 2003.

FERREIRA, G. G. Conservadorismo, fortalecimento da extrema-direita e a agenda da diversidade sexual e de gênero no Brasil contemporâneo. Revista Lutas Sociais, Sáo Paulo, v. 20, n. 36, p.166-178, jan./jun. 2016. Disponível em: https://revistas.pucsp.br/ls/ article/view/31855> Acesso em: 5 out. 2019.

HALLIDAY, M. E. K. Language as a Social Semiotic: the social interpretation of language and meaning. London: Edward Arnold, 1978.

HALLIDAY, M. E. K. An Introduction to Functional Grammar. London: Edward Arnold, 1994.

LIMA, R. R. Conservadorismo e pós-modernidade: as implicaçōes para o serviço social na contemporaneidade. Anais do $16^{\circ}$ Encontro Nacional de Pesquisadores em Serviço Social. Vitória, Espírito Santo, 2018. Disponível em: http://www.periodicos.ufes.br/ ABEPSS/article/download/22139/14654 Acesso em: 3 out. 2019.

MARTINS FERREIRA, D. M. Discurso Feminino e Identidade Social. Săo Paulo: Annablume/Fapesp, 2009 [2002].

MARTINS FERREIRA, D. M. Feminilidade e feminilitude: identidades femininas. Revista 
Intercâmbio, Săo Paulo, v. XXI, pp. 1-16, 2010. Disponível em: https://revistas.pucsp.br/ index.php/intercambio/article/view/4447 Acesso em: 13 jul. 2019.

MARTINS FERREIRA, D. M. Do semelhante ao mesmo, do diferente ao semelhante: sujeito, ator, agente e protagonismo na linguagem. Revista Brasileira de Linguística Aplicada, Belo Horizonte, v. 17, n.4, pp. 619-640, 2017. Disponível em: http://www. scielo.br/scielo.php?script=sci_arttext\&pid=S1984-63982017000400619 Acesso em: 23 jul. 2019.

MAGALHÂES, I. Introduçấo: a análise de discurso crítica. Revista D.E.L.T.A. v. 21, n.especial, p.1-9, 2005. Disponível em: http://www.scielo.br/scielo.php?script=sci_abstract\&pid=S010244502005000300002\&lng=en\&nrm=iso\&tlng=pt Acesso em: 9 out. 2019.

MAGALHÁES, I.; MARTINS, A. R.; RESENDE, V. de M. Análise de Discurso Crítica: um método de pesquisa qualitativa. Brasília: Editora Universidade de Brasília, 2017.

MOI, T. Sexual/Textual Politics: feminist literary theory. London: Routledge, 1995.

OTTONI, P. John Langshaw Austin e a visăo performativa da linguagem. Revista D.E.L.T.A., Sáo Paulo, v.18, n.1, pp. 117-143, 2002. Disponível em: http://www.scielo.br/ scielo.php?pid=S01024502002000100005\&script=sci_abstract\&tlng=pt Acesso em: 10 jul. 2019.

PINTO, J. P. Performatividade radical: ato de fala ou ato de corpo? Revista Gênero, Niterói, v. 3, n. 1, pp. 101-110, 2002. Disponível em: https://www.academia. edu/1456438/performatividade_radical_ato_de_fala_ou_ato_de_corpo Acesso em: 3 jul. 2019.

PINTO, J. P. Conexôes teóricas entre performatividade, corpo e identidades. Revista D.E.L.T.A., Sáo Paulo, v. 23, n.1, pp.1-26, 2007. Disponível em: http://www.scielo.br/ scielo.phppid=S010244502007000100001\&script=sci_abstract\&tlng=pt Acesso em: 3 jul. 2019.

RAMALHO, V; RESENDE, V. de M. Análise de Discurso Crítica. Săo Paulo: Contexto, 2006.

RAMALHO, V; RESENDE, V. de M. Análise de Discurso (para a) Crítica: o texto como material de pesquisa. Sáo Paulo: Pontes Editores, 2011. 


\section{ANEXO \\ FRAGMENTOS DO DISCURSO DA MINISTRA DAMARES ALVES}

[...] Acredito sim, que o menino que tá na escola vai ter que aprender a respeitar menina, o menino lá na escola vai ter que aprender, inclusive, a proteger menina, eu até usei de uma forma simbólica, ensinar o menino a abrir porta do carro, mas eu năo quero que ele apenas abra a porta do carro, deputada, eu quero que ele abra a porta da fábrica, do seu escritório, a porta da sua indústria, eu quero que ele abra a porta dos partidos, quero que ele abra a porta desse parlamento para que mais mulheres estejam aqui também, é isso que eu quis dizer lá naquela época.

[...] Eu náo cometerei injustiça naquela comissáo, deputada, e se eu cometer injustiça, deputada, é bom lembrar que năo se encerra naquela na comissăo, existe poder judiciário, aquele que se sente injustiçado com o meu julgamento poderá buscar no poder judiciário e por último deputada, se mulher deve ser submissa (+) éh, essa é uma fala (+) que eu fiz dentro da minha igreja (+) dentro da doutrina cristă, sim, lá, nós entendemos que dentro do casamento homem e mulher, o homem é o líder do casamento (+) entăo essa é uma percepçăo lá, dentro da minha igreja, da minha fé, eu quero dizer que todas as mulheres văo ter que ser submissas, baixar a cabeça para o patrăo, para o agressor, para os homens que estấo aí? Năo, mas dentro da minha concepçâo cristâ, a mulher sim, no casamento, ela é submissa ao homem e isso é uma questăo de fé, e isso năo me faz menos capaz de dirigir esse ministério, isso năo me faz menos, isso náo me faz mais incompetente, é uma questăo de fé lá dentro do meu segmento.

[...] O tema năo é esse a gente vai ter que se depositar sobre esse assunto, năo fujo da discussăo com relaçăo ao aborto porque eu quero um Brasil sem aborto, eu quero, mas - Brasil sem aborto que eu quero que vocês entendam é que nenhuma mulher precise usar o aborto nessa naçăo, que nenhuma mulher/ eu quero um Brasil sem estupro, porque se nós năo tivermos estupro, nós năo vamos ter mulher lá no serviço de saúde pedindo pra ser/ pra fazer o aborto, eu quero uma naçăo sem aborto, éh, me preocupo com (+) com o que está acontecendo nessa naçấo, éh, com relaçăo a questăo aborto, mas olha, já deixei muito claro, tenho minha posiçấo muita clara com relaçấo a questấo do aborto, sou contra o aborto, todo mundo sabe, mas isso náo vai nortear a política do nosso ministério, eu tenho tanta coisa pra fazer, eu tenho tanta coisa pra fazer naquele ministério que o tema aborto, eu năo vou fazer essa discussăo, a discussăo é do parlamento e agora no judiciário, o que já está aí, a política pública com relaçaáo ao aborto, ela já está aí pelo ministério da saúde, deixa o ministro manter ela lá, deixa o ministro cuidar disso, eu vou cuidar de mulheres, lutar pra a gente salve mulheres, mulheres no ventre materno, mulheres sofridas, mulheres machucadas, esse é meu papel.

[...] nós temos parlamentares jovens, lindas, espetaculares, inteligentes, mulheres de todas as cores, mulheres de todas as raças, temos uma indígena parlamentar, nós precisamos aproveitar esse momento no parlamento, nós precisamos muito aproveitar [...] 
[...] nós temos uma ministra, que é uma mulher empoderada, quem poderia imaginar no passado que uma simples assessora do corretor estaria hoje falando aqui, conduzindo as políticas públicas para mulheres, dá certo, é possível qualquer uma de nós podemos chegar lá, isso é empoderamento da mulher [...]

[...] a gente vem com essa proposta, esse ministério vem, éh, a valorizaçăo da família nas políticas públicas, năo dá mais pra gente construir políticas públicas no Brasil sem a perspectiva da família sem a perspectiva da família, entăo a gente precisa pensar nisso. Éh, eu até citei alguns exemplos, fui mal entendida, năo vou citar exemplos pra năo ser de novo mal entendida, mas nós temos políticas públicas que foram construídas sem pensar na família e a gente precisa pensar na família e quando eu falo família, deputada, eu năo estou falando da família papai e mamăe năo, eu mesmo sou um exemplo de uma família diferente, eu sou mulher (+) sem marido/ ele foi embora, me abandonou, tadinha de mim, foi embora/ e sou măe de uma menina indígena, sou máe sócio afetiva de uma menina indígena, mas nós somos família e ninguém vai tirar isso de mim e de minha filha, nós somos família e esta família, éh, precisa ser fortalecida e todas as configuraçôes familiares precisam ser fortalecidas e a gente tá trabalhando e a secretaria da família vem com uma novidade [...]

[...] A senhora perguntou sobre as mulheres trans, lésbicas, bissexuais, é um desafio, deputada, elas estáo aí, elas existem, elas sofrem, elas sofrem preconceito, elas sofrem violência, éh, o nosso ministério está se debruçando sobre esse tema, o nosso departamento está lá trabalhando, temos uma grande gestora nessa área, temos interagido com os movimentos, temos uma preocupaçăo, que isso fique muito claro.

[...] faltou nesse país muito investimento aos jovens casais, as novas família que estâo sendo organizadas, mas como a senhora vai isso, por exemplo (+) nós estamos discutindo no ministério, todo casal que vai casar no civil tem um edital de proclama e porquê năo falar com esse casal que tá lá, a gente vai acompanhar esse casal, você vai ter seu casamento garantido se você passar por uma palestra, um cursinho, por que năo? por que náo investir/ o estado está impondo/ mas o estado vai ter que assumir seu papel e entender que precisa fazer alguma coisa (+) as vezes de forma impositiva, nós precisamos estar voltando para as famílias que estâo sendo constituídas, especialmente de casais muito jovens[...] 